\title{
Potensi Sinamaldehid sebagai Anti Hiperpigmentasi secara In Silico
}

\section{Cinnamaldehyde Potential as Anti-Hyperpigmentation by In Silico}

\author{
Ni Made Gani Pratiwi ${ }^{10}$, Ni Made Atika Saraswati ${ }^{1}$, Ni Made Irma Febby Prasasti Dewi ${ }^{1}$, \\ Luh Pande Putu Tirta ${ }^{1}$ \\ ${ }^{1}$ Program Studi Farmasi, Fakultas MIPA, Universitas Udayana, Bali
}

\begin{abstract}
Abstrak: Salah satu masalahan kulit yang sering ditemui adalah hiperpigmentasi yang terjadi akibat adanya sintesis melanin berlebihan yang menyebabkan penggelapan warna kulit. Hiperpigmentasi dapat diatasi dengan agen anti hiperpigmentasi yang beraktivitas dalam menghambat proses sintesis melanin. Sintesis melanin dapat dihambat dengan berbagai cara salah satunya dengan menghambat aktivitas tyrosinase. Tyrosinase merupakan enzim yang berperan dalam mengkatalisis proses biosintesis melanin. Sinamaldehid merupakan senyawa bahan alam yang banyak ditemukan pada tanaman Cinnamomum burmanni dan mempunyai aktivitas sebagai antioksidan. Penelitian ini bertujuan untuk mengetahui potensi sinamaldehid dalam menghambat enzim tyrosinase yang akan dibandingkan dengan native liganya secara in silico. Uji in silico dilakukan secara docking molecular dengan tahapan yaitu preparasi dan optimasi sinamaldehid, preparasi tyrosinase serta validasi dan docking. Metode docking molecular telah dinyatakan valid karena RMSD (root mean square distance) yang diperoleh tidak lebih dari 3 Å. Analisis data dilakukan dengan melihat energi ikatan yang dihasilkan dan ikatan yang terbentuk antara senyawa dengan residu asam amino pada protein. Nilai energi ikatan yang diperoleh antara ikatan sinamaldehid dengan tyrosinase adalah-6,21 kkal/mol. Sedangkan energi ikatan antara tyrosinase dengan native ligandnya $-4,79 \mathrm{kkal} / \mathrm{mol}$. Hal tersebut menunjukkan afinitas dari sinamaldehid pada protein tyrosinase lebih besar dibandingkan native ligandnya, sehingga sinamaldehid dikatakan memiliki potensi sebagai anti hiperpigmentasi dengan mekanisme molecular berupa inhibitor protein target tyrosinase sehingga dapat menghambat aktivitas enzim tyrosinase.

Kata Kunci: hiperpigmentasi, in silico, sinamaldehid, tyrosinase.
\end{abstract}

\begin{abstract}
One of skin problem that is often encountered is hyperpigmentation which occurs due to excessive melanin synthesis which causes darkening of the skin colour. Hyperpigmentation can be treated with anti-hyperpigmentation agents which inhibit the melanin synthesis process. Melanin synthesis can be inhibited in various ways, one of which is by inhibiting tyrosinase activity. Tyrosinase is an enzyme that catalyzed the biosynthesis process of melanin. Cinnamaldehyde is an antioxidant. The purpose of this study is to know the potential of cinamaldehyde in inhibiting tyrosinase which will be compared with its native ligand by in silico. The in silico test was carried out by docking molecular which consisted of preparation and optimization of cinnamaldehyde, preparation of tyrosinase as well as validation and docking. The molecular docking method has been declared valid because the RMSD (root mean square distance) obtained is not more than $3 \AA$. Data analysis was obtained by looking at the resulting bond energy and the bonds formed between the compounds and the amino acid residues in the protein. The bond energy score obtained between the cinnamaldehyde and tyrosinase bonds was $-6.21 \mathrm{kcal} / \mathrm{mol}$. Meanwhile, the bond energy between tyrosinase and its native ligand is -4.79 $\mathrm{kcal} / \mathrm{mol}$. This shows that the affinity of cinnamaldehyde on the tyrosinase protein is greater than the native ligand, so that it is said to have potential as an anti-hyperpigmentation with a molecular mechanism in the form of a tyrosinase target protein inhibitor in order to inhibit tyrosinase enzyme activity.
\end{abstract}

Keywords: cinnamaldehyde, hyperpigmentation, in silico, tyrosinase.

\section{PENDAHULUAN}

Paparan sinar ultraviolet (UV) dapat menghasilkan radikal bebas yang bersifat sangat reaktif bagi tubuh. Paparan sinar UV dengan frekuensi yang sering dalam waktu yang relatif lama dapat menyebabkan terjadinya gangguan pada kulit.

\footnotetext{
•email korespondensi: ganiprtw@gmail.com
} 
Proses pembentukan melanin dalam kulit merupakan upaya tubuh manusia untuk melindungi kulit dari aktivitas radiasi ultraviolet sinar matahari. Hiperpigmentasi yaitu suatu gangguan pada kulit karena produksi melanin yang berlebihan, sehingga terjadi penggelapan warna kulit (Wasitaatmadja, 2011). Penambahan melanin yang kurang merata menyebabkan adanya bercak hitam di bagian tertentu pada kulit (Cayce et al, 2004). Hiperpigmentasi kulit dapat diatasi dengan agen anti hiperpigmentasi yang beraktivitas dalam menghambat proses sintesis melanin. Sintesis melanin dapat dihambat dengan berbagai cara salah satunya dengan menghambat aktivitas tyrosinase (Woolery-Lloyd and Kammer, 2011). Tyrosinase merupakan suatu enzim yang memiliki peran mengkatalisis proses biosintesis melanin. Tyrosinase dapat mengkatalis proses oksidasi asam amino Ltirosin menjadi 3,4 dihydroxyphenylalanine (L-DOPA) dan selanjutnya dioksidasi menjadi dopakuinon (Hindritiani dkk., 2013). Dopakuinon diubah menjadi dopakrom melalui proses autooksidasi. Dopakrom kemudian diubah menjadi 5,6 dihidroksi indole-2carboxy acid (DHICA) oleh enzim D-dopachrome tautomerase. DHICA selanjutnya diubah oleh enzim tyrosinase related protein 1 untuk membentuk eumelain, kemudian dikonversi menjadi Indole-5,6quinone carboxylic acid sehingga dapat mensintesis eumelanin merupakan melanin yang berwarna cokelat mengakibatkan penggelapan kulit (Gillbro and Olsson, 2011). Penghambatan enzim melanogenesis menyebabkan proses pembentukkan melanin terhambat sehingga dapat mengatasi permasalahan penggelapan kulit.

Hiperpigmentasi dapat diatasi dengan beberapa cara seperti penggunaan produk pencerah kulit. Beberapa bahan pencerah kulit yang memiliki aktivitas menghambat tyrosinase adalah asam kojat, asam salisilat, arbutin, hidrokuinon, asam sinamat, vitamin C, dan arbutin. Namun demikian, senyawasenyawa tersebut memiliki efek samping yang dapat timbul yaitu asam kojat yang memiliki efek samping dermatitis kontak, iritasi, dan eritema. Penggunaan hidrokuinon menimbulkan permasalahan efek samping seperti iritasi, eritema, okronosis, ruam, pruritik, rasa terbakar hingga bersifat mutagenik
(Woolery-Lloyd and Kammer 2011; Gajjala et al. 2016). Oleh karena itu, perlu dilakukan pengembangan senyawa antihiperpigmentasi yang nantinya dapat menjadi pilihan bagi produsen obat dan kosmetik dalam mengatasi hiperpigmentasi maupun perkembangan produk kosmetik pencerah kulit.

Bahan alam yang dapat dimanfaatkan sebagai agen anti hiperpigmentasi yaitu tanaman kayu manis yang termasuk spesies Cinnamomum burmanii yang merupakan tumbuhan berkayu yang dimanfaatkan sebagai rempah-rempah (Emilda, 2018). Berdasarkan kromatografi cair kinerja tinggi sebanyak 50 gram kayu manis terdapat senyawa eugenol yang memiliki kandungan sebesar 3,11 \%, sedangkan analisis komponen senyawa pada kayu manis menggunakan instrumen GC-MS (Gas Chromatography-Mass Spectroscopy) ditemukan senyawa coumarin sebesar $53,46 \%$ serta senyawa sinamaldehid sebesar 90,24\%. Sinamaldehid merupakan senyawa yang termasuk golongan polifenolat dan turunan dari aldehid.

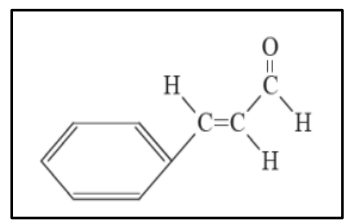

\section{Gambar 1. Struktur Kimia Sinamaldehid (Emilda, 2018).}

Sinamaldehid adalah bahan aktif yang mampu melawan radikal bebas sehingga dapat digunakan sebagai antioksidan. Adanya aktivitas antioksidan yang dimiliki oleh sinamaldehid maka terdapat kemungkinan bahwa sinamaldehid berpotensi sebagai agen anti hiperpigmentasi. Dengan demikian, pada penelitian ini dilakukan molecular docking sebagai uji pendahuluan untuk mengetahui aktivitas sinamaldehid sebagai agen anti hiperpigmentasi dengan menghambat aktivitas dari enzim tyrosinase.

\section{METODE PENELITIAN}

\section{Alat Dan Bahan}

Bahan yang digunakan dalam penelitian ini meliputi struktur 3 dimensi dari sinamaldehid yang dibuat dan dipreparasi pada program Hyperchem 8. 
Sampel struktur protein target tyrosinase (PDB ID: 2Y9X), yang diunduh dari http://www.rcsb.org. Alat yang digunakan pada penelitian ini yaitu seperangkat komputer dengan spesifikasi Windows 10 64-bit dengan program Hyperchem 8 untuk preparasi dan optimasi senyawa uji sinamaldehid, Hyperchem 8 merupakan versi terbaru perangkat lunak Hyperchem dengan kemampuan untuk berinteraksi dengan program lain seperti Microsoft Word dan Microsoft Excel. Chimera 1.11 untuk preparasi protein target, dan Aplikasi AutoDock Tools dilengkapi program Autodock 4.2 dan Autogrid untuk molecular docking.

\section{Prosedur Penelitian}

Beberapa tahapan dalam prosedur penelitian yaitu: Disiapkan database senyawa uji sinamaldehid yang dibuat, dipreparasi dan dioptimasi pada program Hyperchem 8, serta database struktur 3 dimensi protein target yakni Tyrosinase (PDB ID: 2Y9X) diakses dari http://www.rcsb.orG. Protein target dipreparasi menggunakan Chimera 1.11. Validasi metode molecular docking dilakukan dengan re-docking native ligand dengan protein yang telah dipisahkan. Tahap terakhir dilakukan analisis data meliputi nilai jenis ikatan hidrogen dan energi ikatan yang terbentuk.

\section{a. Optimasi Sinamaldehid}

Struktur 3 dimensi senyawa sinamaldehid dibuat dan dioptimasi dengan menggunakan program Hyperchem 8 lengkap dengan atom hidrogennya. Optimasi struktur 3 dimensi senyawa sinamaldehid menggunakan metode kalkulasi dengan single point. komputasi semi-empiris AM1 serta optimasi geometri.

\section{b. Preparasi Protein Target}

Protein target enzim melanogenesis yaitu tyrosinase dipilih strukturnya dalam bentuk aktifnya yaitu dapat berikatan dengan native ligand. Preparasi protein target diawali dengan menghilangkan molekul air $\left(\mathrm{H}_{2} \mathrm{O}\right)$. Tahap selanjutnya dipisahkan native ligand pada protein target menggunakan program Chimera 1.11.1. Tujuan penghilangan native ligand ini adalah untuk memberikan ruang (pocket cavity), sehingga koordinat pocket dan binding site center digunakan untuk bahan docking dapat ketehaui. Native ligan yang telah terpisah tersebut digunakan untuk validasi metode.

\section{c. Validasi Metode}

Validasi metode molecular docking menggunakan program Auto Dock Tools 1.5.6. validasi metode dilakukan dengan re-docking native ligand dari masing-masing protein target yang dipisahkan native ligand-nya. Parameter yang digunakan untuk memvalidasi metode molecular docking adalah nilai RMSD (Root mean square distances) dengan rumus:

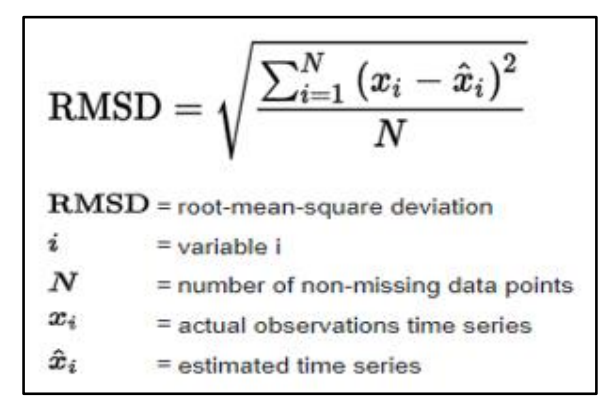

Hasil docking dimana metode dinytakan valid jika nilai RMSD $\leq 3,0 \AA$ (Laksmiani and Nugraha, 2019). Setelah metode yang digunakan valid, docking senyawa uji pada protein target dapat dilakukan.

\section{d. Docking Sinamaldehid}

Senyawa uji sinamaldehid yang telah teroptimasi selanjutnya di-docking-kan para protein target yang telah dipreparasi (dihilangkan native ligand-nya) dengan menggunakan metode yang tervalidasi. Docking dilakukan dengan menggunakan program Aplikasi AutoDock Tools dilengkapi program Autodock 4.2 dan Autogrid. Hasil yang diperoleh dari proses docking sinamaldehid pada protein target ini adalah nilai jenis ikatan hidrogen dan energi ikatan yang terbentuk, kemudian dilakukan analisis terhadap hasil yang diperoleh

\section{e. Analisis Data}

Analisis data yang dilakukan dengan metode deskrptif. Hasil molecular docking yang didapat yaitu jenis ikatan hidrogen dan energi ikatan yang terbentuk antara senyawa dengan protein target. Jenis ikatan hidrogen yang terbentuk antara sinamaldehid dengan protein target digunakan untuk analisis mekanisme model interaksi yang terbentuk antara senyawa uji sinamaldehid dengan 
residu asam amino dari protein target. Sedangkan energi ikatan yang diperoleh digunakan untuk analisis afinitas dari sinamaldehid terhadap protein target tirosinase. Hasil energi ikatan yang negatif menunjukkan bahwa senyawa memiliki afinitas terhadap protein target sedangkan apabila bernilai positif maka senyawa uji tidak memiliki afinitas terhadap protein target ataupun memiliki afinitas yang sangat lemah. Hasil energi ikatan yang diperoleh dari sinamaldehid dibandingkan untuk mengetahui potensi sinamaldehid sebagai anti hiperpigmentasi.

\section{HASIL DAN PEMBAHASAN}

\section{Optimasi Struktur 3D Senyawa Sinamaldehid}

Struktur 3 dimensi dari sinamaldehid dilakukan preparasi dan optimasi terlebih dahulu dengan menggunakan aplikasi Hyperchem 8 untuk mendapatkan struktur yang lebih stabil, yang ditandai dengan energi total yang rendah. Proses ini berfungsi untuk menurunkan energi ikatan pada senyawa sehingga didapatkan struktur yang stabil. Program Hyperchem 8 menggunakan metode perhitungan mekanika kuantum $a b$ initio dan semi empiris. Metode semi empiris memiliki tingkat akurasi yang lebih tinggi saat menghitung nilai eksperimen dan waktu pengoperasiannya lebih cepat daripada metode ab initio. Pada penelitian ini digunakan metode semi empiris AM1 (Austin Model 1) karena model $A M 1$ adalah model semi empiris yang mampu menghitung optimasi geometri, sifat elektronik dan energi total dari model yang bersangkutan dan memiliki kemampuan memperkirakan gugus $\mathrm{H}$ lebih baik dibandingkan metode lainnya (Hypercube, 2002).
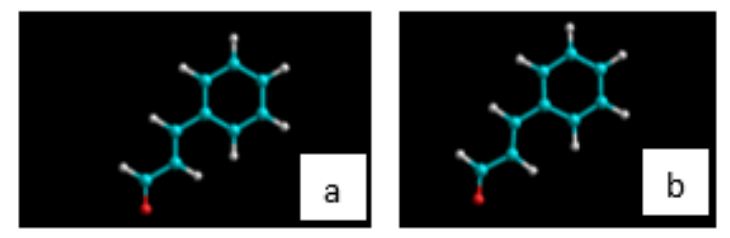

Gambar 2. Optimasi Struktur Sinamaldehid.

a) Energi lkatan: -2003,645662 kkal/mol

Proses optimasi struktur 3 dimensi sinamaldehid meliputi perhitungan single point yang kemudian dilanjutkan dengan optimasi geometri. Kalkulasi single point adalah perhitungan yang digunakan untuk menentukan energi total molekul dari struktur tanpa suatu proses optimasi struktur senyawa uji. Optimasi geometri adalah suatu proses untuk penurunan energi total sehingga diperoleh struktur senyawa uji yang paling stabil, dari struktur senyawa uji (Adnyani et al., 2019). Energi total pada proses single point yang diperoleh adalah $2003.645662 \mathrm{kkal} / \mathrm{mol}$ sedangkan besar energi hasil optimasi geometri yang diperoleh adalah -2009.1472 kkal/mol. Dilihat dari kedua hasil tersebut menunjukkan bahwa energi total pada optimasi geometri lebih besar dibandingkan energi total pada kalkulasi single point.

\section{Preparasi Protein Target}

Preparasi dilakukan terhadap struktur 3D protein target yaitu tyrosinase. Tujuan dari dilakukannya preparasi protein adalah untuk memperoleh struktur protein target tanpa native ligand yang akan digunakan dalam proses validasi metode. Preparasi protein target pada penelitian ini dilakukan dengan menggunakan aplikasi Chimera 1.11. 4 rantai yang dimiliki oleh protein tyrosinase dengan PDB ID: 2Y9X yaitu rantai A, B, C, dan D. Dari keempat rantai tersebut memiliki semua memiliki native ligand yang sama yaitu tropolone (OTR) dengan rumus molekul $\mathrm{C}_{7} \mathrm{H}_{6} \mathrm{O}_{2}$. OTR memiliki aktivitas sebagai inhibitor tyrosinase (Ismaya et al., 2011). Penelitian ini menggunakan satu rantai untuk preparasi yaitu rantai A dengan native ligand OTR. Hasil dari preparasi protein ditunjukkan pada Gambar 2.
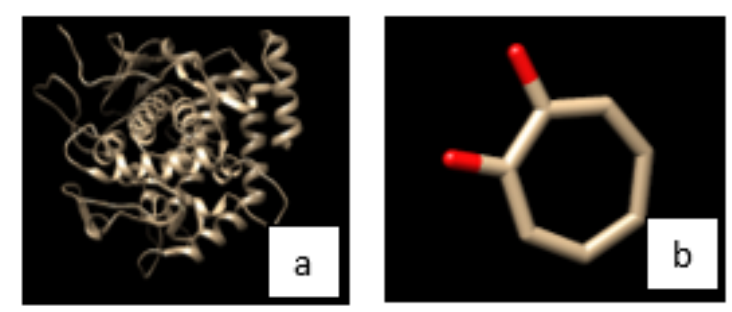

Gambar 3. (a). tyrosinase tanpa ligan. (b) native ligan tropolone (OTR)

\section{Validasi Metode}

Validasi metode merupakan suatu penilaian terhadap parameter untuk menentukan bahwa nilai parameter tersebut memenuhi persyaratan dalam 
penggunaanya, sehingga hasil analisis oleh metode tersebut dapat dipercaya. Parameter yang digunakan dalam menentukan validitas dari suatu metode docking adalah nilai RMSD (Root Mean Square Distances). Batas nilai nilai RMSD yang dapat diterima yaitu $\leq 3 \AA$ (Jain and Nicholls, 2008). Validasi metode molecular docking dilakukan dengan menggunakan aplikasi AutoDockTools 1.5 .6 yang dilengkapi dengan program Autodock4 dan Autogrid4.

Proses validasi metode molecular docking menggunakan AutoDockTools diawali dengan menginput struktur protein target ke dalam aplikasi, kemudian dilakukan penambahan atom hidrogen pada protein target tersebut. Penambahan atom hidrogen ini bertujuan untuk menambahkan valensi molekul sehingga keadaan optimum ikatan hidrogen dari protein (Morris et al., 2009). Tahapan selanjutnya adalah dilakukan pengaturan grid box. Pengaturan grid box dilakukan dengan menyesuaikan ukuran koordinat grid center dan grid size sehingga dapat mempersingkat eksplorasi koordinat antara protein dengan ligand dalam mengevaluasi posisi optimasi ikatan pada sisi aktif protein (Feinstein, W. P., 2015). Pengaturan grid box meliputi pengaturan posisi dan dimenasi $x, y$, dan $z$ koordinat interaksi antara native ligand dengan protein taget. Nilai koordinat grid box untuk validasi metode dapat dilihat pada Tabel 1.

Tabel 1. Hasil Validasi Metode

\begin{tabular}{ccccc}
\hline Konformasi & $\begin{array}{c}\text { Energi } \\
\text { Ikatan } \\
\text { (kkal/mol) }\end{array}$ & $\begin{array}{c}\text { RMSD } \\
(\mathbf{A})\end{array}$ & $\begin{array}{c}\text { Asam Amino } \\
\text { yang } \\
\text { Berikatan }\end{array}$ & $\begin{array}{c}\text { Ikatan } \\
\text { Hidrogen }\end{array}$ \\
\hline $\mathbf{1}$ & -4.84 & 2.19 & HIS61 & HE2-OA2 \\
$\mathbf{2}$ & -4.81 & 2.16 & HIS61 & HE2-OA2 \\
$\mathbf{3}$ & -4.82 & 2.18 & HIS61 & HE2-OA2 \\
$\mathbf{4}$ & -4.81 & 2.21 & HIS61 & HE2-OA2 \\
$\mathbf{5}$ & -4.79 & 2.06 & HIS61 & HE2-OA2 \\
$\mathbf{6}$ & -4.82 & 2.19 & HIS61 & HE2-OA2 \\
$\mathbf{7}$ & -4.80 & 2.17 & HIS61 & HE2-OA2 \\
$\mathbf{8}$ & -4.82 & 2.19 & HIS61 & HE2-OA2 \\
$\mathbf{9}$ & -4.83 & 2.18 & HIS61 & HE2-OA2 \\
$\mathbf{1 0}$ & -4.84 & 2.16 & HIS61 & HE2-OA2 \\
\hline
\end{tabular}

Hasil validasi metode molecular docking yaitu nilai RMSD yang diperoleh untuk protein tyrosinase $2.06 \AA$, konformasi yang digunakan pada tyrosinase adalah konformasi 5 . Berdasarkan nilai RMSD yang diperoleh, diketahui bahwa metode yang digunakan dapat dikatakan valid dikarenakan nilai
RMSD $\leq 3 \AA$, sehingga proses docking sinamaldehid dapat dilakukan yang diperoleh.

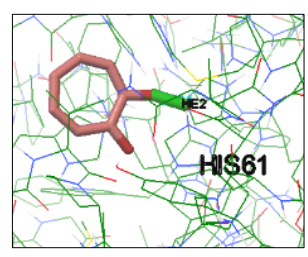

\section{Gambar 4. Visualisasi Hasil Validasi Metode Konformasi 5}

\section{Docking Sinamaldehid pada Protein Target}

Docking senyawa sinamaldehid yang telah dioptimasi pada tyrosine dilakukan dengan menggunakan aplikasi AutoDockTools 1.5.6 yang dilengkapi dengan program Autodock4 dan Autogrid4. Senyawa yang digunakan untuk docking dengan tyrosinase yaitu sinamaldehid yang memiliki protensi sebagai anti hiperpigmentasi. Proses docking senyawa sinamaldehid pada protein target memperoleh hasil berupa nilai jenis ikatan hidrogen dan energi ikatan yang terbentuk antara sinamaldehid dengan protein target.

Nilai energi ikatan yang diperoleh antara ikatan sinamaldehid dengan tyrosinase adalah-6,21 $\mathrm{kkal} / \mathrm{mol}$. Energi ikatan yang negatif telah memberikan gambaran bahwa sinamaldehid dapat berinteraksi dengan protein target. Energi ikatan yang dihasilkan sinamaldehid lebih negatif dibandingkan dengan ikatan tyrosinase dengan native ligandnya yaitu sebesar $-4,79 \mathrm{kkal} / \mathrm{mol}$ yang menandakan bahwa afinitas sinamaldehid terhadap tyrosinase lebih besar dibandingkan native ligand. Selain nilai energi ikatan, data yang diperoleh dari hasil docking sinamaldehid dengan protein target yaitu ikatan hidrogen yang terbentuk antara senyawa dengan residu asam amino pada protein. Visualisasi interaksi antara sinamaldehid dengan tyrosinase dapat dilihat pada Tabel 2. Ikatan anatar native ligand dengan tyrosinase memiliki memiliki satu ikatan hydrogen yang berikatan pada residu asam amino HIS61. Senyawa uji sinamaldehid dengan tyrosinase juga membentuk ikatan hydrogen yang melibatkan residu asam amino HIS61 dan HIS85. Adanya kesamaan residu asam amino yang terlibat antara sinamaldehid dan native ligand dengan protein target menunjukkan bahwa 
sinamaldehid mampu menempati posisi yang sama dengan native ligand sehingga memiliki aktivitas yang sama seperti native ligand dalam menginhibisi tyrosinase.

Tabel 2. Hasil Docking Sinamaldehid dengan Tyrosinase

\begin{tabular}{cccc}
\hline Konformasi & $\begin{array}{c}\text { Energi lkatan } \\
\text { (kkal/mol) }\end{array}$ & $\begin{array}{c}\text { Asam Amino } \\
\text { yang } \\
\text { Berikatan }\end{array}$ & $\begin{array}{c}\text { Ikatan } \\
\text { Hidrogen }\end{array}$ \\
\hline $\mathbf{1}$ & -6.20 & HIS61 & HE2-O \\
HIS85 & HE2-O \\
\multirow{2}{*}{$\mathbf{3}$} & -6.21 & HIS61 & HE2-O \\
& & HIS85 & HE2-O \\
\multirow{2}{*}{$\mathbf{4}$} & -6.20 & HIS61 & HE2-O \\
& & HIS85 & HE2-O \\
$\mathbf{5}$ & -6.20 & HIS61 & HE2-O \\
\multirow{2}{*}{$\mathbf{6}$} & -6.20 & HIS85 & HE2-O \\
& & HIS61 & HE2-O \\
\multirow{2}{*}{$\mathbf{1 0}$} & -6.20 & HIS85 & HE2-O \\
& & HIS61 & HE2-O \\
\multirow{2}{*}{$\mathbf{8}$} & -6.20 & HIS85 & HE2-O \\
& & HIS61 & HE2-O \\
& -6.20 & HIS61 & HE2-O \\
& & HIS85 & HE2-O \\
& -6.20 & HIS61 & HE2-O \\
& & HIS85 & HE2-O \\
& & HIS61 & HE2-O \\
\hline
\end{tabular}

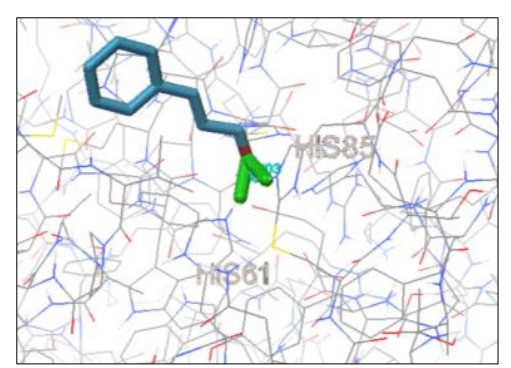

\section{Gambar 5. Visualisasi Hasil Docking pada} Konformasi 2

Berdasarkan dari energi ikatan yang dihasilkan, energi ikatan antara sinamaldehid dengan tyrosinase bernilai negative sehingga memiliki afinitas terhadap tyrosinase dan berpotensi menginhibisi tyrosinase (Chang, 2009). Perbandingan hasil docking sinamaldehid dengan native ligand yang memiliki aktivitas menghambat tyrosinase menunjukkan binding site yang sama sehingga sinamaldehid memiliki potensi sebagai inhibitor dari tyrosinase.

\section{SIMPULAN}

Sinamaldehid memiliki afinitas terhadap tyrosinase dan menghasilkan energi ikatan yang negatif. Berdasarkan hasil docking sinamaldehid memiliki potensi sebagai antihiperpigmentasi secara in silico dengan menghambat enzim tyrosinase.

\section{DAFTAR PUSTAKA}

Adnyani, K. D. et al. (2019) 'AKTIVITAS DARI KUERSETIN SEBAGAI AGEN PENCERAH KULIT SECARA IN SILICO', Jurnal Kimia (Journal of Chemistry), pp. 207-212. doi: 10.24843/JCHEM.2019.V13.I02.P14.

Cayce, K. A., Amy, J. M. and Steven, R. F. (2004) 'Hyperpigmentation: An Overview of the Common Afflictions', Dermatol Nurs, 16(5), pp. 401-416.

Chang, T. S. (2009) 'An updated review of tyrosinase inhibitors', International Journal of Molecular Sciences, 10(6), pp. 2440-2475. doi: 10.3390/ijms10062440.

Emilda (2018) 'Efek Senyawa Bioaktif Kayu Manis Cinnamomum burmanii NEES EX.BL.) Terhadap Diabetes Melitus: Kajian Pustaka', Jurnal Fitofarmaka, 5(1), pp. 246-252.

Feinstein, W. P., \& M. B. (2015) 'No TitleCalculating an Optimal Box Size for Ligan Docking and Virtual Screening Against Experimental and Predicted Binding Pockets', Journal of Cheminformatics, 7(18), pp. 1-10.

Gajjala, S. et al. (2016) 'The comparative study of Hydroquinone and kojic acid in treatment of Melasma in Shadan Institute of Medical Science Teaching Hospital and Research Centre, Himayathsagar road, Hyderabad (Telangana State)', IOSR Journal of Dental and Medical Sciences (IOSR-JDMS) e-ISSN, 15(11), pp. 1-05. doi: 10.9790/08531511050105.

Gillbro, J. M. and Olsson, M. J. (2011) 'The melanogenesis and mechanisms of skinlightening agents - Existing and new approaches', International Journal of Cosmetic Science, 33(3), pp. 210-221. doi: 10.1111/j.1468-2494.2010.00616.x. 
Hypercube (2002) Hyperchem Release 7: Tools for Molecular Modelling. Canada: Hypercube Incorporation.

Ismaya, W. T. et al. (2011) 'Crystal Structure of Agaricus bisporus Tyrosinase', Biochemistry, 50, pp. 5477-5486.

Jain, A. N. and Nicholls, A. (2008) 'Recommendations for evaluation of computational methods', Journal of Computer-Aided Molecular Design, 22(3-4), pp. 133-139. doi: 10.1007/s10822-008-9196-5.

Laksmiani, N. P. L. and Nugraha, I. P. W. (2019) 'Depigmentation activity of secang (Caesalpinia sappan L.) Extract through tyrosinase, tyrosinase related protein-1 and dopachrome tautomerase inhibition', Biomedical and Pharmacology Journal, 12(2), pp. 799-808. doi: 10.13005/bpj/1703.
Morris, G. M. et al. (2009) 'AutoDock4 and AutoDockTools4: Automated docking with selective receptor flexibility', Journal of Computational Chemistry, 30(16), pp. 27852791. doi: 10.1002/jcc.21256.

Wasitaatmadja, S. . (2011) Dermatologi Kosmetik. Edisi Kedu. Jakarta: Fakultas Kedokteran Universitas. Indonesia.

Woolery-Lloyd, H. and Kammer, J. N. (2011) 'Treatment of Hyperpigmentation', Seminars in Cutaneous Medicine and Surgery, 30(3), pp. 171-175. doi: 10.1016/j.sder.2011.06.004. 